\title{
A Structured Assessment System for an Undergraduate Civil Engineering Program
}

\author{
Stephen J. Ressler, Thomas A. Lenox \\ United States Military Academy
}

\section{INTRODUCTION}

The purpose of this paper is to describe a comprehensive assessment system, currently in use in the civil engineering program at the United States Military Academy. The system consists of two principal components: (1) a set of eight program objectives; and (2) a wide array of assessment tools, used to routinely evaluate how well the program objectives are being met.

\section{PROGRAM OBJECTIVES}

The eight USMA civil engineering program objectives (identified as PO1 through P08) are stated below:

\section{Design, coordinate, and execute a civil engineering program that produces graduates who:}

- understand the engineering thought process, by which mathematics and science are applied to the solution of technological problems confronting mankind. (PO1)

- can solve problems creatively. (P02)

- have a broad base of knowledge in civil engineering, represented by the structural, environmental, hydro, and geotechnical discipline areas; and depth of knowledge in the structural or environmental discipline area. (PO3)

- understand the multi-faceted challenges facing civil engineers in professional practice. (PO4)

- $\quad$ use the computer effectively and appropriately as a problem-solving tool. (PO5)

- $\quad$ write and speak effectively. (PO6)

- $\quad$ are prepared for and motivated toward continued intellectual and professional growth. (P07)

Develop and maintain a faculty that serves as a model of professional excellence for our cadets. (PO8)

Objectives PO1 through P07 emanate directly from the institution's published Academic Program Goals. These objectives are focused on the principal products of our program--our graduates--and on the qualities and skills we expect them to possess as a direct consequence of their undergraduate education. The relatively broad scope of the objectives reflects the fact that our graduates will all serve as commissioned officers in the U.S. Army, and therefore must possess capabilities well beyond the mastery of the technical aspects of civil engineering. 
Objective P08 derives from the Academy's broader purpose of producing leaders of character, inspired to a lifetime of service to the nation. Our contribution to leader development lies primarily in the example set by our faculty--military and civilian--who serve not only as educators, but also as professional role models for our cadets. In addition to their duties as civil engineering instructors, our faculty members routinely serve as academic counselors, military trainers, officers-in-charge of athletic teams and extracurricular clubs, honor and ethics advisors, and mentors. And in every interaction with cadets, they must communicate in word and deed what it means to be a professional. Therefore we consider our efforts to promote and develop the professional excellence of our faculty to be an integral component of our academic program.

\section{ASSESSMENT TOOLS}

In evaluating how well we achieve our program objectives, we have taken a broad view of the term "assessment". Accordingly, our assessment system reflects three guiding principals:

(1) Assessment should occur at every level of the program. We assess student performance in nearly every lesson of every course. We do it again in a more comprehensive manner after each block of instruction ends, as each academic term ends, and as a given group of students successfully completes the program. Finally, we do a global assessment of the capabilities of our graduates periodically, after they have left the institution.

(2) All students and all members of the faculty should participate in the assessment process. Individual instructors and course directors assess student performance in their courses. Students assess their own performance and that of the faculty at the end of each course and upon completion of the program. The program director assesses how well each course contributes to the program objectives, administers program-level surveys and evaluations, and incorporates all internally- and externally-administered assessments into the global program assessment.

(3) Assessment should be done as a routine part of program management. Assessments should be accomplished as regularly scheduled events--surveys, reports, and coordination meetings--which ensure continuous, routine generation of assessment data. These data must be linked to a mechanism for identifying deficiencies and making corrective actions, if the assessment system is to result in bona fide improvement of the program.

In keeping with these principals, we employ the following assessment tools:

Time Survey. This simple but effective tool documents the time spent by students in out-of-class preparation for each lesson. It is administered at the start of every class attendance, in every course taught by the Department of Civil and Mechanical Engineering. For the individual instructor, the time survey provides feedback on how much time students are spending on class preparation, homework, projects, and examinations. For the program director, the survey provides a reasonably accurate assessment of the relative academic rigor of the courses which constitute the program. More important, time survey data for successive offerings of the same course clearly indicate an increase or decrease in academic rigor over time, and thus provide an indirect measure of trends in student proficiency*.

*For more information on the use of time surveys, see Ressler and Lenox, "The Time Survey; ACourse Development Tool That Works," elsewhere in these Proceedings. 
Graded Requirements. Graded requirements are an essential means of assessing students' mastery of their discipline. We use many different types of graded requirements for assessment. Some of our courses use daily graded homework to formally assess students' capabilities on a lesson-by-lesson basis. Without exception, courses that do not use daily homework use quizzes or homework sets (called special problems) to provide an assessment after each major block of instruction (normally 3 to 5 lessons). All courses administer at least one mid-term examination and all courses except the Capstone design course have a comprehensive final exam. These examinations provide successively broader evaluations of students' command of civil engineering subjects. All courses which include engineering design content use design projects to assess students' ability to apply the design process in a given subject area (e.g., steel, concrete, drainage systems). These projects also provide a means of evaluating creativity, communication skills, and the ability to use the computer as a problem-solving tool.

Course Journal. In our Civil Engineering Seminar course (CE-400A), we require students to keep a journal documenting their participation in the course. CE-400A is focused on professional practice issues and is taken by all civil engineering majors in their final semester of undergraduate study. Thus the CE-400A journal is a valuable tool for assessing students' understanding of the challenges facing engineers in professional practice.

Course-End Survey. A USMA standard course-end survey is administered to all students at the conclusion of every course. The survey provides the instructor with timely feedback on students' perceptions of course content, quality of instruction, rigor, and relevance. As part of the survey, students assess how well the course contributed to their understanding of the subject, to their creativity, and to their desire to learn more about the subject.

Course Summary and Critique Report. Upon receipt of the course-end survey results, the course director prepares a final written report, containing his or her own assessment of the course, along with the student critiques. The report is submitted to the program director for review and approval. The program director uses the report to assess how well the students have achieved course objectives and, to a lesser extent, how well the instructor is performing in the classroom. The director may recommend changes to be made in the next iteration of the course.

The Course Proposal Meeting. This meeting is conducted once annually for each course in the program, normally several months before the start of the semester in which the course is offered. In the meeting, the course director briefs the program director and the senior civil engineering faculty on the content and administration of the course, with emphasis on proposed changes from the previous offering. Problems or deficiencies noted in the Course Summary and Critique Report are addressed here. Through this process, the director assesses (and adjusts, as required) all aspects of course and program content. Once the program director has approved the course director's proposal, a formal Course Proposal Report is prepared to document the decision.

Capstone Projects. The senior-level Capstone design course functions as a final quality control check on the USMA civil engineering program. In the course project, students are required to develop a comprehensive design of a low-rise commercial building, which includes substantive structural, geotechnical, hydrologic/hydraulic, environmental engineering, and economics content. To succeed, they must demonstrate proficiency in each of these areas, and must synthesize the different components into a single coherent product. By design, the Capstone project is intended to incorporate every major component of the civil engineering 
program; thus, to some extent, students' performance on the project can be used as a qualitative gauge of the entire program.

CE Survey of Graduating Seniors. This survey is administered annually to graduating seniors who have majored in civil engineering. Through this vehicle, students are afforded the opportunity to provide a global assessment of the quality of instruction and content of the entire CE program. They are asked to comment about how well they understand the engineering thought process and the various topics which comprise the civil engineering discipline. They also assess their own communication and computer skills, as well as their desire for continued intellectual and professional growth.

Fundamentals of Engineering Examination results. At US MA, all students enrolled in ABET -accredited engineering programs are required to take the FE exam. The exam results provide a consistent and thoroughly objective basis for assessing how well students understand the fundamental concepts of engineering.

USMA Survey of Graduating Seniors. This survey is administered annually to all graduating seniors, regardless of major. It is used by USMA to assess the extent to which the institution's Academic Program Goals have been achieved. Because the civil engineering program objectives derive directly from the USMA Academic Program Goals, data from this survey are directly applicable to the CE program assessment. By extracting statistical summaries of the responses made by civil engineering majors, the program director can obtain students' selfassessments of their ability to apply the engineering thought process, solve problems creatively, use computers, and communicate effectively. Students' responses also indicate their desire for continued intellectual growth and their evaluation of the quality of instruction they received at USMA.

Rotating faculty input. Approximately $75 \%$ of the US MA faculty consists of active duty Army officers. The majority of these officers are USMA graduates, who serve for seven to ten years in the field, attend graduate school, then return to the Academy for three-year tours of duty on the faculty. Their success rate in gaining acceptance to and successfully completing high-quality graduate programs is a direct measure of the effectiveness of their US MA education. In the civil engineering program, these instructors are all Corps of Engineers officers-engineering practitioners with extensive field experience. Their presence on the faculty provides a continuous source of input on the relevance of the program, and the extent to which the program prepares its graduates to function effectively in engineering practice.

USMA Engineering Graduates Survey. This assessment instrument provides a systematic follow-up of USMA graduates' performance in engineering or engineering-related positions, both in and out of the Army. The survey is administered by the USMA Office of Institutional Research every six years, in conjunction with the ABET accreditation visit. Its purpose is to obtain input from the graduates of all USMA engineering programs on the perceived effectiveness of their engineering education at US MA, as preparation for professional practice.

\section{ASSESSMENT TOOLS VS. OBJECTIVES}

Figure 1 shows the relationship between the assessment tools described above and the civil engineering program objectives. The matrix shows the assessment tools in the first column, followed by the level at which each assessment is targeted. The remainder of the matrix consists of eight columns, one for each of the program objectives. An X in a particular cell of the matrix indicates that the assessment tool is used to evaluate the corresponding objective. 
Placement of the individual X's in the matrix follows directly from the discussion of assessment tools above. The aggregate effect is a rich, multi-dimensional assessment system, in which:

- every objective is assessed by at least four different tools,

- every objective is assessed on at least two different levels (e.g., course and program), and

- every assessment tool is used to evaluate at least two different objectives.

Thus the program director has both flexibility and redundancy in assessing program outcomes, and is not likely to be biased by over-reliance on a single source of information.

\begin{tabular}{|c|c|c|c|c|c|c|c|c|c|}
\hline I. & 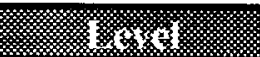 & & & Woby & 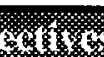 & (x) & Sisil & & \\
\hline & & (3) & (3) & 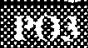 & 308 & 3 & 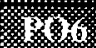 & (3) & 103 \\
\hline Time Survey & $\begin{array}{l}\text { Lesson, Block, } \\
\text { and Course }\end{array}$ & & & $\mathrm{x}$ & & & & & \\
\hline Daily Homework & Lesson & & & $\mathrm{X}$ & & & & & \\
\hline Quiz & $\begin{array}{l}\text { Block of } \\
\text { Instruction }\end{array}$ & & & $\mathrm{x}$ & & & & & \\
\hline Special Problem & $\begin{array}{l}\text { Block of } \\
\text { Instruction }\end{array}$ & & & $\mathrm{x}$ & & $\mathrm{X}$ & $\mathrm{x}$ & & \\
\hline Mid-Term Exam & $\begin{array}{l}1 / 3 \text { to } 1 / 2 \text { of } \\
\text { Course }\end{array}$ & & & $\mathrm{X}$ & & & & & \\
\hline Design Project & $\begin{array}{l}\text { Block or } \\
\text { Course }\end{array}$ & $\mathrm{x}$ & $x$ & $x$ & & $x$ & $\mathrm{x}$ & & \\
\hline Final Exam & Course & & & $\mathrm{x}$ & & & & & \\
\hline Journal (CE-400A) & Course & & & & $\mathrm{x}$ & & & $\mathrm{X}$ & \\
\hline Course-End Surveys & Course & & $\mathrm{x}$ & $\mathrm{x}$ & & & & $\mathrm{X}$ & $\mathrm{x}$ \\
\hline $\begin{array}{l}\text { Course Summary and } \\
\text { Critique Report }\end{array}$ & Course & & & $x$ & & & & & $x$ \\
\hline Course Proposal & Course & & & $\mathrm{x}$ & & & & & \\
\hline Capstone Projects & Program & $\mathrm{x}$ & $\mathrm{x}$ & $x$ & $\mathrm{x}$ & $\mathrm{x}$ & $\mathrm{x}$ & & \\
\hline $\begin{array}{l}\text { CE Survey of Graduating } \\
\text { Seniors }\end{array}$ & Program & $\mathrm{x}$ & & $\mathrm{x}$ & & $\mathrm{X}$ & $\mathrm{x}$ & $\mathrm{x}$ & $\mathrm{x}$ \\
\hline $\begin{array}{l}\text { Fundamentals of Engineering } \\
\text { Exam }\end{array}$ & Program & & & $\mathrm{x}$ & & & & $\mathrm{x}$ & \\
\hline $\begin{array}{l}\text { USMA Survey of Graduating } \\
\text { Seniors }\end{array}$ & Program & $\mathrm{x}$ & $\mathrm{x}$ & & & $\mathrm{x}$ & $\mathrm{x}$ & $\mathrm{x}$ & $\mathrm{x}$ \\
\hline Rotating Faculty Feedback & Program & & & $\mathrm{x}$ & $\mathrm{X}$ & & & $\mathrm{x}$ & \\
\hline $\begin{array}{l}\text { US MA Engineering } \\
\text { Graduates Survev }\end{array}$ & Program & $\mathrm{x}$ & $\mathrm{x}$ & & $\mathrm{x}$ & $\mathrm{x}$ & $\mathrm{x}$ & $\mathrm{X}$ & $\mathrm{x}$ \\
\hline
\end{tabular}

Figure 1. Matrix of Associations Between Assessment Tools and Program Objectives. 


\section{CONCLUSION}

We have described the comprehensive, multi-dimensional assessment system currently in use in the civil engineering program at the United States Military Academy. Though the system is clearly tailored for USMA, we believe that our wide array of assessment tools and our structured methodology for associating assessment tools with objectives will be useful to educators and program directors at other institutions as well,

Note: The authors will provide copies of the USMA Standard Course-End Survey, the CE Survey of Graduating Seniors, and the USMA Engineering Graduates Survey to any engineering educators who wish to use them.

Send requests to:

LTC Stephen Ressler

Department of Civil and Mechanical Engineering

West Point, NY 10996

E-mail: is8874@westpoint-emh2 .army.mil

\section{LIEUTENANT COLONEL STEPHEN J. RESSLER}

LTC Stephen J. Ressler is an Associate Professor in the Dept. of Civil and Mechanical Engineering at the U. S. Military Academy, West Point, and is a registered professional engineer in Virginia. He graduated from USMA in 1979 and received a Ph.D. degree from Lehigh University in 1991. He has taught courses in statics and dynamics, mechanics of materials, steel design, reinforced concrete design, and design of structural systems.

\section{COLONEL THOMAS A. LENOX}

COL Thomas A. Lenox is a Professor of Civil Engineering at the United States Military Academy, and the Director of USMA's Civil Engineering Program. He holds leadership positions in the CE Division, the Mech Division, and the Middle-Atlantic Section of ASEE. 